\title{
Risk Management Assessment on Human Resource Information Technology Services using COBIT 5
}

\author{
Muhammad Nur Fuad \\ Department of Information System \\ Universitas Ahmad Dahlan \\ Yogyakarta of Indonesia
}

\author{
Imam Riadi \\ Department of Information System \\ Universitas Ahmad Dahlan \\ Yogyakarta of Indonesia
}

\begin{abstract}
Human Resources in Higher Education is engaged in the development of lecturers and employees, the main business process uses Information Technology as its service base. Business processes can run properly then it takes risk management, Human Resources in Higher Education requires risk management to the business process that runs. COBIT 5 is here to address the challenges of this modern era, especially in risk management. The need for a risk assessment to measure how far risk management is applied by elements in Human Resources in Higher Education, the purpose of the study is knowing capability level values, Gap values, and recommendations based on the results of risk management assessments. The risk management assessment in this study uses the COBIT framework 5 domain process APO12 including the stages of data collection, risk analysis, risk profile, articulating risk, risk tolerance value, and how to respond to risk. Research Method using Quantitative Analysis. The data was obtained using questionnaire dissemination techniques, direct observes, and interviews calculated using the Guttman method. RACI Chart is supportive in determining appropriate respondents. The results of the study found a capability level value in domain APO12 of 2.60 meaning at this level the implementation of business processes in Human Resources in higher education has carried out planning, supervision, and adjustment, and its work has been established, observed, and maintained properly. APO12 has a Gap value of 1 level this is the basis for making recommendations. This research has gone well following the expected research objectives.
\end{abstract}

\section{Keywords}

Risk Management, Capability Level, Gap, RACI Chart, Guttman

\section{INTRODUCTION}

Information technology services to provide data and information needs. The use of information technology makes it easy to run every business process with an organization or company. Problems arise in terms of IT risk management so that the organization's goals are not achieved properly. A risk management assessment is carried out aimed at assessing early opportunities that allow for the impact of risk, the small amount of risk impact posed depending on how quickly we know the IT risks that will arise and then choose the right risk re-linking alternatives.

Human Resources in higher education already conducts risk management on its work culture but not in accordance with COBIT 5 standards, evidenced by the absence of maturity value to risk at this time. Basically an organization needs a risk assessment to be able to map the quality of risk both posistive and negative that will be posed, to support the analysis that COBIT 5 will do present to measure and assess the potential risks that will be posed so that it will be given recommendations on the potentials that will arise based on the calculation of gap values.

Business processes conducted by Human Resources in higher education do not yet have Risk Management standards, in other words all business processes carried out do not have a risk benchmark as a basis in carrying out business processes. While the APO12 domain itself is an early stage domain used for risk management. APO12 domains have 6 sub domains including collecting data, analyzing risks, maintaining risk profiles, understanding risks, minimizing the impact of tolerable risks and how to respond to risks.

\subsection{Literature Studies}

\subsubsection{Previous Research}

The study stage of literature is done to provide a reference to add knowledge in conducting research, there are 6 references cited in this study. Previous research has been conducted by Soejanto and Perdanakusuma (2018) with the title of the student from Universitas Brawijaya with the title Of Information Technology Governance Evaluation at PT. Aerofood Indonesia Soekarno Hatta Cengkareng Airport using COBIT 5 Framework. The results of this study are capability value on domain DSS01 3 level, DSS02 2 level, DSS03 2 level and there is a gap value 1 level. [1]. Arief (2018) student from Universitas Brawijaya title of Information Technology Risk Management Evaluation Using COBIT Framework 5 case study at PERUM Jasa Tirta 1 Malang. The results of this study domain EDM03 2 level, APO12 2 level and there is a value of 1 Gap. [2] Setyaningrum, Suprapto, and Kusyanti (2018) students from Universitas Brawijaya with the title Of Risk Management Evaluation of Information Technology Using COBIT Framework 5 case study: PT. Kimia Farma Persero Tbk Plant Watukandon. The results of this study domain EDM03 2 level and APO12 1 level. [3]. Megawati and Ana (2018) students from UIN SUSKA University with the title Of Information Technology Risk Management Evaluation Using COBIT Framework 5 case study: PT Pegadaian. The results of this study domain EDM03 1 level. [4]. Firdaus (2018) student from Universitas Brawijaya with the title Evaluation of Information Technology Risk Management Using COBIT 5 case study: PT. Gresik Petrochemicals. The results of this study domain EDM03 2 levels and APO12 3 levels. [5] Nanda Putra Wandita (2014) a student from Syarif Hidayatullah State Islamic University Jakarta under the title Evaluation of Information Technology Governance in Remote Education System Using COBIT Framework 5. The results of this study domain BAI07 2 levels. [6]. The difference in the development of this research is the use of a RACI chart which helped determine respondents and also the use of calculations 
using the Guttman scale which has the advantage of a fast and effective calculation process.

\subsubsection{COBIT 5 (Control Objective for Information and Related Technology)}

ISACA (2012) COBIT 5 provides a comprehensive framework that assists companies in achieving their goals for IT corporate governance and management. New user demands, industry-level regulations, and risk data emerging daily and a focus on companies in the field of information technology that offers flexibility are part of why using the COBIT 5 framework. [7]. COBIT 5 provides domains for ITrelated risk management, those domains are APO12 (Risk Management). In APO12 there are steps contained in it are the steps of collecting data, risk management, maintaining a risk profile, understanding risk, lowering the risk impact to tolerance level and how to respond to risk

\subsubsection{Implementation of COBIT 5}

ISACA (2012) how to implement COBIT 5 needs to pay attention to the following points:

1. The relevant parties who become the main actors in running the wheels of business processes that are supporters of change and create a desire to achieve the goals that are then realized in the form of new processes, controllers can be sourced from internal and external parties as well as the existence of enabling issues to be supporters of the driver of change.

2. IT objectives with the company's strategy and risk are commensurate and prioritize the company's objectives, IT objectives and IT processes most importantly. Providing reference and tolerance limits of awareness in other words the insinuation between its objectives and existing risks.

3. Set targets to create improvements, which are then followed by a gap analysis to identify alternatives to relevant solutions that are quick and profitable. Recommendations are derived based on known difference values with relevant calculation steps to determine the right recommendations.

4. Plan the right solution to execute immediately, monitor, and ensure ongoing business risk. The selection of the right alternative can be a major factor in the success of risk prevention so that the risk impact does not cause great harm to an organization or company. The appropriate response is certainly done by stakeholders who understand the situation and condition of the organization by making deliberations before determining alternatives.

5. Calculate and monitor the system to ensure businesses do not change the direction of goals that are then carried out with day-to-day activities.

6. Focus on the ongoing shift revolution of improved management and management practices towards businesses and monitoring achievements from improvements using performance schemes.

Evaluation of achievement goals to identify governance needs and increase needs continuously.

\subsubsection{APO12 (Risk Management)}

APO12 domain is a domain contained in COBIT 5, APO12 is focused on its risk management. The 6 subdomains related to APO12 are:
1. APO12-01 (Collecting Data)

The domain contains official rules on the stages of how to technically collect data.

2. APO12-02 (Analyzing Risk)

Domains contain rules relating to technical IT risk analysis.

3. APO12-03 (Maintaining Risk Profile)

Contains rules relating to efforts to retain assets in response to the impact of IT risk.

4. APO12-04 (Articulate Risk)

Domains that contain technical rules in the step of determining the right tangents by the relevant stakeholders.

5. APO12-05 (Lowers risk impact)

Contains rules to minimize the impact of IT risk.

6. APO12-06 (Respond to Risk)

A domain that contains rules about how to determine the appropriate action after an IT risk occurs.

\subsubsection{RACI Chart}

The RACI Chart method aims to determine the appropriate respondents with the rules of APO12. Organizational RACI Chart is a tool to help determine decision making and assist organizations in identifying employee roles and responsibilities. aims to avoid overlapping positions that affect employee performance.RACI Chart APO12 can be seen in Figure1:

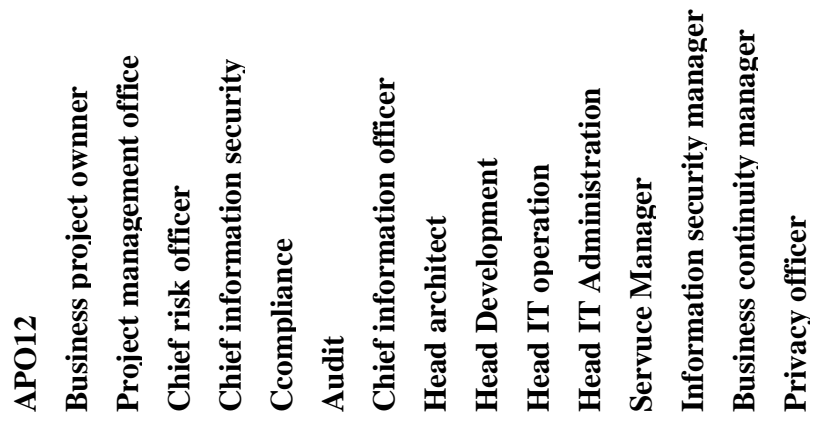

$\begin{array}{llllllllllllllll}\mathbf{1} & \mathbf{R} & \mathbf{R} & \mathbf{R} & \mathbf{R} & \mathbf{C} & \mathbf{C} & \mathbf{A} & \mathbf{R} & \mathbf{R} & \mathbf{R} & \mathbf{R} & \mathbf{R} & \mathbf{R} & \mathbf{R} & \mathbf{R}\end{array}$

$\begin{array}{llllllllllllllll}2 & \mathbf{R} & \mathbf{C} & \mathbf{R} & \mathbf{C} & \mathbf{R} & \mathbf{R} & \mathbf{A} & \mathbf{C} & \mathbf{C} & \mathbf{C} & \mathbf{C} & \mathbf{C} & \mathbf{C} & \mathbf{C} & \mathbf{C}\end{array}$ $\begin{array}{llllllllllllllllll} & \mathbf{B} & \mathbf{R} & \mathbf{C} & \mathbf{A} & \mathbf{C} & \mathbf{R} & \mathbf{R} & \mathbf{R} & \mathbf{C} & \mathbf{C} & \mathbf{C} & \mathbf{C} & \mathbf{C} & \mathbf{C} & \mathbf{C} & \mathbf{C}\end{array}$ $\begin{array}{llllllllllllllll}4 & \mathbf{R} & \mathrm{C} & \mathbf{R} & \mathrm{C} & \mathrm{C} & \mathrm{C} & \mathrm{A} & \mathrm{C} & \mathrm{C} & \mathrm{C} & \mathrm{C} & \mathrm{C} & \mathrm{C} & \mathrm{C} & \mathrm{C}\end{array}$ $\begin{array}{llllllllllllllll}\mathbf{5} & \mathbf{R} & \mathbf{C} & \mathbf{A} & \mathbf{C} & \mathbf{C} & \mathbf{C} & \mathbf{R} & \mathbf{C} & \mathbf{C} & \mathbf{C} & \mathbf{C} & \mathbf{C} & \mathbf{C} & \mathbf{C} & \mathbf{C}\end{array}$ $\begin{array}{llllllllllllllll}\mathbf{6} & \mathbf{R} & \mathbf{R} & \mathbf{R} & \mathbf{R} & \mathbf{C} & \mathbf{C} & \mathbf{A} & \mathbf{R} & \mathbf{R} & \mathbf{R} & \mathbf{R} & \mathbf{R} & \mathbf{R} & \mathbf{R} & \mathbf{R}\end{array}$

\section{Figure 1. RACI Chart APO12}

Based on Figure 1. Work units can be viewed in the APO12 domain. RACI Chart or referred to as Responsible, Accountable, Consulted, and Informed. Responsible is the person responsible as the business wheel driving actor, the accountable actor who makes decisions, the Consulted actor in charge of providing direction and input on business processes and Informed is an actor who must know the final information on the chosen alternative.

\subsubsection{Respondent Data Processing}

Data processing uses Guttman calculation methods by using 
Microsoft Excel as a counting tool. The calculation starts based on the answers of 1 respondent in each domain APO12. Calculation of the weight value of the questionnaire, if the value [Y] then according to the Guttman Scale has a value of 1 , whereas if the value [T] then it has a value of 0 . Calculations are managed based on respondents' answers on each domain. The processing of respondent data can be seen in Table 1:

Table 1. Guttman Scale

\begin{tabular}{c}
\hline average $: \frac{\text { answer weight }}{\text { number of questions }}$ \\
\hline normality $: \frac{\text { average amount }}{\text { the average number of all level }}$ \\
\hline level normalization $:$ normalization ${ }^{*}$ level
\end{tabular}

Calculation of average, normality, and normalization of levels.

\subsubsection{Level Capability Value}

ISACA (2012) measures the value of appropriate capabilities using technical data collection with interviews sourced from speakers who have competence in their field. The goal of assessing level capabilities can also be interpreted as measuring an entity to support the achievement of the organization's goals. 6 capability assessment levels:

\section{Level 0-incomplete process}

The purpose of the process is not to run at all so that it can be said to fail to achieve the goals of the organization as well as the absence of supporting documents.

\section{Level 1-Performed Process}

The purpose of the process has been achieved which is then implemented and has fulfilled the supporting documents. The goal that must be achieved at level 1 is to measure how much the goal of the process is achieved and produce output that is in line with expectations.

\section{Level 2-Managed Process}

The process has been implemented following the previous level, but there needs to be improvements related to planning, supervision, and adjustment. Attribute goals at this level by measuring how much the process is governed by and how much output the goal has achieved.

\section{Level 3-Established Process}

Processes at this level have been well managed and define the achievement of the results of the process. There are two attributes at this level that are by measuring how much the process is defined to support the implementation of the process and measuring how much the standard process has been implemented effectively.

\section{Level 4-Predictable Process}

The process is already operating following the standards of the organization's needs. There are two attributes of the process at this level, which is to measure how much assessment results are used to support the achievement of the organization's objectives and to explore how much the process is quantitatively regulated to produce stable output following the standard stipulated needs.

\section{Level 5-Optimizing Process}

The process is continuously improved so that the goals of the current organization will have brilliant goals in the future. The attribute of the process at this level is to measure how much process changes are identified by taking innovative approaches and measuring how much changes are defined, effectively managing process execution to support the achievement of process improvement goals.

\section{METHODOLOGY}

\subsection{Research Stage}

Research activities are a process of obtaining or obtaining knowledge to solve problems faced, carried out scientifically, systematically, and logically. In conducting research there are similarities in determining the stages of research, it's just that sometimes it is necessary to adjust to the research needs.

This research will discuss the Risk Management Assessment of Information Technology Services in Human Resources in Universities that have not implemented risk management on ongoing business processes following COBIT 5 standards. Objects will be focused on Information Technology Services using the COBIT 5 framework. A study will be able to be said to run if it has standards that will be taken until it reaches its expected final destination. This research will be referenced following the stages contained in COBIT 5 to carry out the research to be conducted.

The research phase that will be conducted in this study will be described with a flowchart as a reference step achieved until this research is considered complete. Stages from the early stage to the final stage as a limit of motion in conducting research. The research stages will be described in Figure 2:

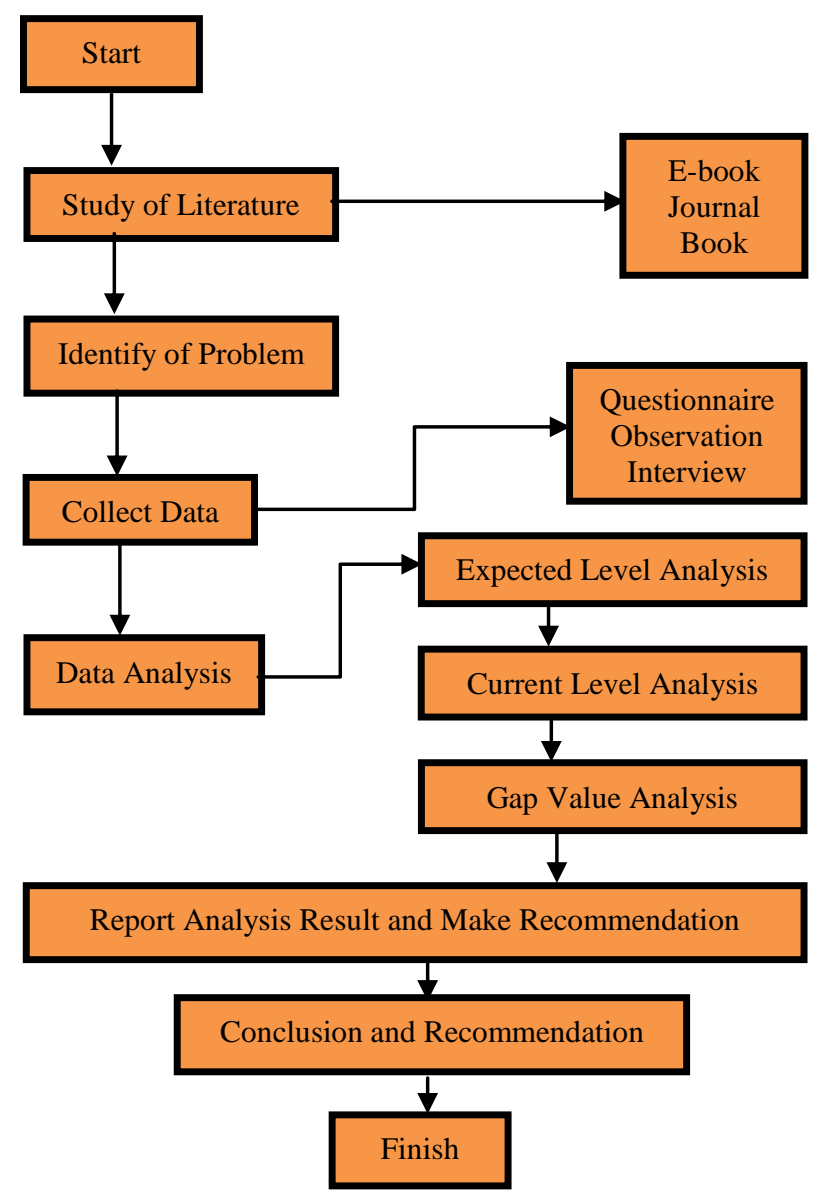

Figure 2. Research Stage

The research stage includes 6 steps in outline as follows: 
1. The first stage of the researcher will begin to research by conducting a literature study as an early stage, the literature study is done by collecting references to either the journal or the book. There are 6 journals cited, of course, journals used by research in the last 3 years and 1 book on COBIT 5.

2. The second stage identifies the problem, this stage researchers make observations directly in Human Resources at the Higher Education to get the results of the problem. Synchronizing the problem with the method taken namely COBIT 5 and mapping the position using the RACI method Chart.

3. The third stage is to collect data. Techniques for collecting data using media Questionnaires, observations, and interviews.

4. The fourth stage performs data analysis. First, the researchers will assess the maturity value of the current level of capability by processing the questionnaire data, then the researcher will conduct an assessment of the maturity value of the desired level capability and the last time the researcher performs a gap assessment.

5. The fifth stage of the researcher will make recommendations according to each domain that has a gap value, the follow-up is that if the recommendation is implemented the organization will have the advantage of being able to reach the desired level. Recommendations will then be reported to human resources in universities as input material to improve the desired level.

6. The sixth stage of the researchers will distribute suggestions and conclusions in conducting research based on known results.

\subsection{Tools and Materials}

The tools and materials used in this study are divided into two types, namely research supporting software in processing data and supporting hardware in conducting research. Research tools and materials as seen in Table 2:

Table 2. Tools and Materials

\begin{tabular}{|l|l|}
\hline \multicolumn{1}{|c|}{ Software } & \multicolumn{1}{|c|}{ Hardware } \\
\hline $\begin{array}{l}\text { 1. Operating System } \\
\text { Windows 10 pro 64 bit }\end{array}$ & $\begin{array}{l}\text { 1. Processor Intel Celeron }{ }^{\circledR} \\
\text { N1350 1.60 GHz }\end{array}$ \\
\hline $\begin{array}{l}\text { 2. Tools Microsoft Word and } \\
\text { Microsoft Excel 2016 }\end{array}$ & $\begin{array}{l}\text { 2. Random Access Memory } \\
2.00 \mathrm{~Gb}\end{array}$ \\
\hline $\begin{array}{l}\text { 3. Snipping tool and } \\
\text { Drawing.io }\end{array}$ & 3. Type memory HDD 1 Tb \\
\hline
\end{tabular}

Based on table 2 is a tool and material used as supporting material in conducting IT Risk Management research.

\subsection{Implementation}

\subsubsection{Collecting Data}

The research method used is a quantitative analysis method with technical data collection using questionnaires, interviews, and observations.

\subsubsection{1 questionnaires}

The determination of respondents is done using the RACI chart method, aiming to be precise and results more accurate. Researchers have distributed questionnaires to prospective respondents. Technically, the researchers carried out data accumulation using the RACI Chart method, a method that directly distinguishes work units based on the Job-description of the Stakeholders, so that the questionnaire will be validly accepted by the person responsible for IT services in university human resources. RACI Chart mapping results can be found in Table 3:

Table 3. RACI Chart Respondent Mapping Result

\begin{tabular}{|c|c|c|c|}
\hline No. & Unit $C O B I T 5$ & \multirow{13}{*}{ 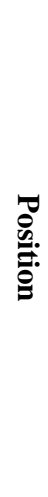 } & ID \\
\hline 1. & Business process owner & & R5 \\
\hline 2. & Project Management Office & & $\mathrm{R} 1$ \\
\hline 3. & Chief risk officer & & $\mathrm{R} 2$ \\
\hline 4. & Chief information security officer & & R3 \\
\hline 5. & Head architect & & $\mathrm{R} 2$ \\
\hline 6. & Head development & & $\mathrm{R} 4$ \\
\hline 7. & Head IT operations & & R3 \\
\hline 8. & Head IT administration & & R3 \\
\hline 9. & Service Manager & & $\mathrm{R} 2$ \\
\hline 10. & Information security manager & & R3 \\
\hline 11. & Business continuity manager & & R1 \\
\hline 12. & Privacy officer & & R2 \\
\hline
\end{tabular}

Based on Table 3 above the results of the RACI Chart mapping of the APO12 domain in Human Resources in higher education there are 12 units, but there are people who have doubled performance. The result is that 5 respondents will be the respondents in the questionnaire.

\subsubsection{Observastion and Interviews}

Aim to obtain valid data and information so that the results of the research can be maintained until completion.

1. The expected Capability level value is 3 levels.

2. The organization's overview of human resources business processes at universities has implemented IT risk management but not yet like the COBIT 5 standard and full control of the system.

3. Financial and Assets are external parties that assist human resources in universities to achieve the organization's goals.

4. SOP documents for acceptance of prospective employees or lecturers and college work unit documents.

5. Human Resources in universities have made the classification of IT risks against the risks that have occurred

6. The absence of an effective benchmark to measure the success rate of employees or lecturers in training.

7. Many IT-related business risks are identified but not documented in the form of visible Databases, but only verbally.

8. In response to potential IT risks, efforts to maintain current business processes are weighed when making sudden changes that could pose a greater potential IT risk.

\subsubsection{Data Analysis}

Data analysis has several steps to take. Aim to process data so that it can help in making decisions and conclusions of the research.

\subsubsection{Current Capability Analysis}

Processing the respondent's data by performing calculations using the Guttman method to find out the value of the current level of capability. The current level of capability value can be seen in Table 4: 
Table 4. Current APO12 Calculations Result

\begin{tabular}{|c|l|c|}
\hline Domain & \multicolumn{1}{|c|}{ Proccess } & Current Level \\
\hline APO12.01 & Collecting Data & 2.69 \\
\hline APO12.02 & Analyzing Risk & 2.60 \\
\hline APO12.03 & Maintaining Risk Profile & 2,75 \\
\hline APO12.04 & Articulate Risk & 2,68 \\
\hline APO12.05 & Lowers risk impact & 2.78 \\
\hline APO12.06 & Respond to Risk & 2,27 \\
\hline
\end{tabular}

The value of Capability APO12 (Risk Management) is currently known through Guttman calculations that have a value of 2.60 (Managed Process). the result is obtained by calculating the average known Current Level value in each APO12 (Risk Management) domain. Achieving a value of 2.60 means that the implementation of business processes at Human Resource in universities has implemented planning, supervision, and adjustment, and the work has been set, observed, and maintained properly, but needs a slight improvement to reach the desired level.

\subsubsection{Expected Capability Analysis}

The value of the capability desired by human resources in higher education is 3 levels. Grade 3 is obtained by providing education directly to human resources in universities when providing an understanding of IT Risk Management. Briefing is carried out to provide an understanding of IT Risk Management including containing level capability assessments. The result of the submission of this material is an agreement between the educational and human resources authorities in the Higher Education that sets the desired value to be at level 3 .

\subsubsection{Gap Analysis}

The gap is obtained from the calculation of the value of known capabilities. Comparison between the current capability value and the desired capability value. It is known that in each domain APO12 has an average value of 2.60 while the desired capability value is at level 3 of the above comparison result then there is a Gap value of 1 level on each domain used. gaps can be analyzed by comparing the findings of the questionnaire to the results of observations and interviews. The comparison will produce a counter-statement where the reality and the respondents' questionnaire answers do not have the right synchronization.

\subsubsection{Assessment Results}

In this sub, the chapter will be presented a known value. The results of calculating the level capability value can be seen in Table 5:

Table 5. APO12 Comparison Value Level

\begin{tabular}{|c|l|c|c|c|c|}
\hline Domain & \multicolumn{1}{|c|}{ Proses } & $\begin{array}{c}\text { Curre } \\
\boldsymbol{n} \boldsymbol{t}\end{array}$ & $\begin{array}{c}\text { Expect } \\
\boldsymbol{e d}\end{array}$ & $\begin{array}{c}\text { Ma } \\
\boldsymbol{x}\end{array}$ & $\begin{array}{c}\boldsymbol{G} \boldsymbol{a} \\
\boldsymbol{p}\end{array}$ \\
\hline $\begin{array}{c}\text { APO12. } \\
01\end{array}$ & Collecting Data & 2.69 & 3 & 5 & 1 \\
\hline $\begin{array}{c}\text { APO12. } \\
02\end{array}$ & Analyzing Risk & 2.60 & 3 & 5 & 1 \\
\hline $\begin{array}{c}\text { APO12. } \\
03\end{array}$ & $\begin{array}{l}\text { Maintaining Risk } \\
\text { Profile }\end{array}$ & 2,75 & 3 & 5 & 1 \\
\hline $\begin{array}{c}\text { APO12. } \\
04\end{array}$ & Articulate Risk & 2,68 & 3 & 5 & 1 \\
\hline
\end{tabular}

\begin{tabular}{|c|l|c|c|c|c|}
\hline Domain & \multicolumn{1}{|c|}{ Proses } & $\begin{array}{c}\text { Curre } \\
\boldsymbol{n t}\end{array}$ & $\begin{array}{c}\text { Expect } \\
\boldsymbol{e d}\end{array}$ & $\begin{array}{c}\mathbf{M a} \\
\boldsymbol{x}\end{array}$ & $\begin{array}{c}\boldsymbol{G a} \\
\boldsymbol{p}\end{array}$ \\
\hline $\begin{array}{c}\text { APO12. } \\
\text { 05 }\end{array}$ & $\begin{array}{l}\text { Lowers risk } \\
\text { impact }\end{array}$ & 2.78 & 3 & 5 & 1 \\
\hline $\begin{array}{c}\text { APO12. } \\
06\end{array}$ & Respond to Risk & 2,27 & 3 & 5 & 1 \\
\hline
\end{tabular}

Based on Table 5 above it can be concluded that Human Resources in Higher Education reach level 2 with a gap value 1 level in all existing domains. The known gap value will be reduced to become material for further investigations so that it can produce an IT risk recommendation with the aim that human resources in higher education can reach the desired level.

Level completeness assessment is the process of checking the need for supporters to be eligible for level achievement in each APO12 domain. Here are the results of the examination of the needs of the supporters. Based on the results of the capability level assessment APO12 has reached level 2 in APO12 to be able to prove that human resources have been valid then universities must have complete data needs at level 1 (performed process), level 2 (managed process). Here is the completeness of the data needs that have been owned by SDM UAD by APO12 at level 1 as seen in table 6 :

\section{Table 6. Completeness of Data Level 1 Performed Process}

\begin{tabular}{|c|l|c|}
\hline \multicolumn{3}{|c|}{ PA 1.1 (Process Performed) } \\
\hline Domain & \multicolumn{1}{|c|}{ Goal } & Description \\
\hline APO12.01 & Collect risk data for analysis & $\checkmark$ \\
\hline APO12.02 & Analyze risk data & $\checkmark$ \\
\hline APO12.03 & Maintain risk attributes & $\checkmark$ \\
\hline APO12.04 & $\begin{array}{l}\text { Provide IT risk opportunity } \\
\text { information }\end{array}$ & $\checkmark$ \\
\hline APO12.06 & $\begin{array}{l}\text { Manage opportunities to } \\
\text { minimize risk } \\
\text { risks }\end{array}$ & $\checkmark$ \\
\hline
\end{tabular}

Based on table 6 completeness of data to reach level 2 have all been met, in other words, Level 1 can be interpreted with the PA scale (process attribute) has an attribute value of $>85 \%$ $100 \% \mathrm{~F}$ (fully achieved). Furthermore, to be eligible for level 2, UAD human resources should have most of the completeness of performance management and product management data as seen in the table 7 :

Table 7. Completeness of Data Level 2 Managed Process in Performance Management

\begin{tabular}{|c|c|c|c|}
\hline \multirow{2}{*}{$\begin{array}{c}\text { PA } 2.1 \text { (Performed } \\
\text { Management) }\end{array}$} & \multirow{2}{*}{ Evidence } & \multicolumn{2}{|c|}{ Description } \\
\hline & & yes & no \\
\hline $\begin{array}{l}\text { Scope of Risk } \\
\text { Management }\end{array}$ & $\begin{array}{l}\text { The } \\
\text { organizational text } \\
\text { of the work units } \\
\text { of the college }\end{array}$ & $\checkmark$ & \\
\hline $\begin{array}{l}\text { Risk Management } \\
\text { Objectives }\end{array}$ & $\begin{array}{l}\text { The } \\
\text { organizational text } \\
\text { of the work units } \\
\text { of the college }\end{array}$ & $\checkmark$ & \\
\hline $\begin{array}{l}\text { College human } \\
\text { resources response } \\
\text { if it doesn't meet } \\
\text { targets }\end{array}$ & 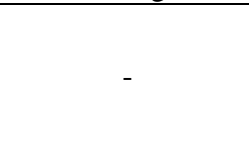 & & $\checkmark$ \\
\hline RACI Stakeholder & - & & \\
\hline
\end{tabular}




\begin{tabular}{|c|c|c|c|}
\hline Management Chart & & & \\
\hline $\begin{array}{l}\text { Criteria for } \\
\text { Admission of } \\
\text { Employees and } \\
\text { Lecturers }\end{array}$ & $\begin{array}{l}\text { College human } \\
\text { resources training } \\
\text { and recruitment } \\
\text { manual }\end{array}$ & $\checkmark$ & \\
\hline $\begin{array}{l}\text { Employee and } \\
\text { Lecturer Training }\end{array}$ & $\begin{array}{l}\text { College human } \\
\text { resources training } \\
\text { and recruitment } \\
\text { manual }\end{array}$ & $\checkmark$ & \\
\hline $\begin{array}{l}\text { Risk Management } \\
\text { Meeting }\end{array}$ & - & & $\checkmark$ \\
\hline
\end{tabular}

Based on table 7 several supporting documents have not been met on performance management APO12 (risk management). That way at this stage with a rating on P (Partially achieved) which means there is some evidence there and some achievement of process attributes being assessed. Furthermore, in the Work Product table the completeness can be seen in table 8 :

Table 8. Completeness of Data Level 2 Managed Process on Work Product

\begin{tabular}{|l|l|c|c|}
\hline \multicolumn{1}{|c|}{$\begin{array}{c}\text { Goal Work } \\
\text { Product }\end{array}$} & \multicolumn{1}{c|}{ Evidence } & \multicolumn{2}{c|}{ Description } \\
\cline { 2 - 4 } $\begin{array}{l}\text { Skin criteria and } \\
\text { work of } \\
\text { employees and } \\
\text { lecturers }\end{array}$ & $\begin{array}{l}\text { College human } \\
\text { resources training and } \\
\text { recruitment manual }\end{array}$ & $\checkmark$ & No \\
\hline $\begin{array}{l}\text { Determining the } \\
\text { needs and work } \\
\text { of employees and } \\
\text { lecturers }\end{array}$ & $\begin{array}{l}\text { Standard Document of } \\
\text { Operational Procedures } \\
\text { of Employees and } \\
\text { Lecturers calculation of } \\
\text { numbers }\end{array}$ & $\checkmark$ & \\
\hline $\begin{array}{l}\text { Documentation of } \\
\text { the work of } \\
\text { employees and } \\
\text { lecturers }\end{array}$ & $\begin{array}{l}\text { Monthly Report } \\
\text { Document of } \\
\text { Employees and } \\
\text { Lecturers of calculation } \\
\text { of numbers }\end{array}$ & $\checkmark$ & \\
\hline $\begin{array}{l}\text { Evaluation of the } \\
\text { work of } \\
\text { employees and } \\
\text { lecturers }\end{array}$ & $\begin{array}{l}\text { Monthly Report } \\
\text { Document of } \\
\text { Employees and } \\
\text { Lecturers of calculation } \\
\text { of numbers }\end{array}$ & $\checkmark$ & \\
\hline
\end{tabular}

Based on a table of 8 the work of employees and lecturers is largely fulfilled. If calculated by process attribute rating then it has reached the value of F (Fully Achieved) on $100 \%$ of the document has been fulfilled. An APO12 comparison chart can be found in Figure 3:

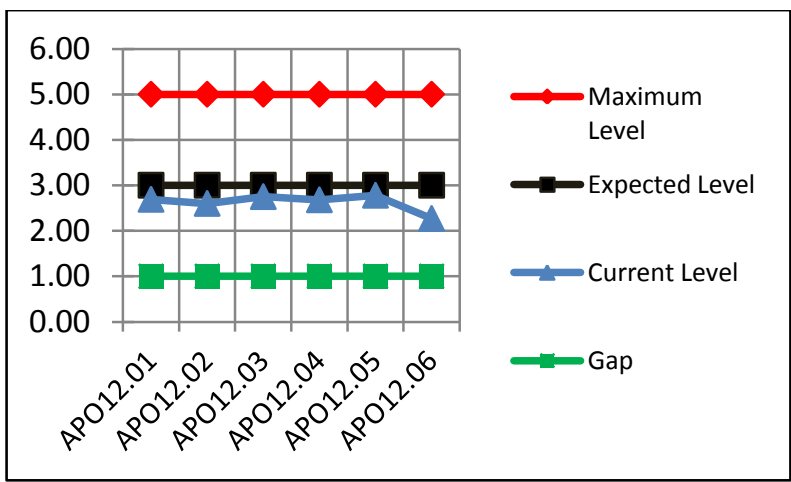

Figure 3. APO12 Comparison Chart
The graph presents valid data according to the assessment results. Human Resources in tertiary institutions have 1 gap value which is then followed up by making recommendations to be implemented to reach the desired level, namely 3 levels.

\subsubsection{Recommendations and Reporting of Result}

At this stage, the researcher makes recommendations based on the domain that has a Gap value. Recommendations are in the form of suggestions and relevant directions so that they can be accepted and implemented by elements of human resources in higher education. Implement it by human resources at universities to improve IT Risk Management. It is necessary to know that the questionnaire findings were obtained from the respondents' answers which were accumulated into one based on the identity of each question from each level which was then compared with the results of observations and interviews. the results of the recommendations APO12.01 can be seen in Table 9:

Table 9. APO12.01 Recommendation Results

\begin{tabular}{|l|l|}
\hline Domain & \multicolumn{1}{c|}{ Recommendation } \\
\hline \multirow{7}{*}{ a. Human Resources in tertiary institutions } \\
must have a regular schedule. Continue aims \\
to make IT risk data classifications that \\
change every period. \\
b. Human Resources in tertiary institutions \\
should add an ideal IT staff to be able to \\
assist in carrying out tasks and distribute job \\
descriptions including IT risk management \\
and also need to coordinate with external \\
parties related to IT to conduct joint \\
evaluations. \\
c. Human Resources in higher education need \\
to increase the utilization of the results from \\
documenting the history of IT risks. \\
d. Human Resources in tertiary institutions \\
should document any risks that have occurred \\
so that they can be used as evaluation \\
materials to avoid the risk of the same IT \\
happening again. Documentation is physical, \\
such as in the form of soft files or hard files. \\
e. Before starting a new business process, \\
Human Resources in higher education need \\
to do careful planning including assessing the \\
IT risks that occur and need to increase joint \\
evaluation activities. \\
f. Human Resources Leaders in higher \\
education should add staff or special fields \\
that are closely related to IT risk analysis so \\
that all kinds of IT risks can be immediately \\
identified
\end{tabular}

The recommendations in the APO12.01 domain have 6 published IT risk management recommendations. Human resources in tertiary institutions are required to implement these recommendations to reach the next level. Level assessment needs to be carried out for analysis of how much level has been achieved after the implementation of recommendations is carried out. the results of the recommendations APO12.02 can be seen in Table 10: 
Table 10. APO12.02 Recommendation Results

\begin{tabular}{|c|c|}
\hline Domain & Recommendation \\
\hline APO12.02 & $\begin{array}{l}\text { a. Human Resources in tertiary institutions in } \\
\text { training activities for employees and lecturers } \\
\text { should add material to discuss IT risk } \\
\text { management. } \\
\text { b. Human Resources in higher education should } \\
\text { make improvements by improving and } \\
\text { implementing risk management related to IT } \\
\text { services. } \\
\text { c. Human Resources in tertiary institutions } \\
\text { should have objective standards related to IT } \\
\text { risk, it is necessary to map IT risk so that it } \\
\text { can be used as standard value in measuring } \\
\text { the level of IT risk impact, so that it helps in } \\
\text { making decisions. } \\
\text { d. Human Resources in higher education should } \\
\text { have internal or external coordination to } \\
\text { assist in finding opportunities for IT risks } \\
\text { that may occur. }\end{array}$ \\
\hline
\end{tabular}

The recommendations in the APO12.02 domain have 4 published IT risk management recommendations. Human resources in tertiary institutions are required to implement these recommendations to reach the next level. Level assessment needs to be carried out for analysis of how much level has been achieved after the implementation of recommendations is carried out. the results of the recommendations APO12.03 can be seen in Table 11:

Table 11. APO12.03 Recommendation Results

\begin{tabular}{|l|l|}
\hline Domain & \multicolumn{1}{c|}{ Recommendation } \\
\hline \multirow{7}{*}{ APO12.03 } & $\begin{array}{l}\text { a. Human Resources in tertiary institutions } \\
\text { should have a concept that describes how } \\
\text { risks will arise in the future, so that when IT } \\
\text { risks arise, Human Resources in universities } \\
\text { are ready, of course, with stakeholders who } \\
\text { are responsible for responding to IT risks and } \\
\text { have the courage to make decisions. } \\
\text { b. Human Resources in higher education should } \\
\text { have indicators of success in achieving a } \\
\text { business process related to IT risk. Includes } \\
\text { employee and lecturer success indicators } \\
\text { after attending the training. } \\
\text { c. Human Resources in higher education should } \\
\text { be able to assess the average size of the } \\
\text { impact of IT risk based on the classification } \\
\text { to make the right decision. } \\
\text { d. Human Resources in higher education should } \\
\text { have regulations that are ready to respond to } \\
\text { future IT risks }\end{array}$ \\
\hline
\end{tabular}

The recommendations in the APO12.03 domain have 4 published IT risk management recommendations. Human resources in tertiary institutions are required to implement these recommendations to reach the next level. Level assessment needs to be carried out for analysis of how much level has been achieved after the implementation of recommendations is carried out. the results of the recommendations APO12.04 can be seen in Table 12:
Table 12. APO12.04 Recommendation Results

\begin{tabular}{|c|c|}
\hline Domain & Recommendation \\
\hline APO12.04 & $\begin{array}{l}\text { a. Human Resources in tertiary institutions } \\
\text { should have a relationship with BIFAS in } \\
\text { addition to being supporting actors but also } \\
\text { needing to be appraisal actors for Human } \\
\text { Resources in tertiary institutions. Assessment } \\
\text { includes performance and IT-related policies. } \\
\text { b. Human Resources in tertiary institutions } \\
\text { should make SOPs in managing IT-related } \\
\text { business processes, including determining } \\
\text { when an actor is required to analyze gaps that } \\
\text { may cause big losses. } \\
\text { c. Human Resources in higher education should } \\
\text { have regulations to find the right alternatives } \\
\text { after the impact of IT risks that occur. }\end{array}$ \\
\hline
\end{tabular}

The recommendations in the APO12.04 domain have 3 published IT risk management recommendations. Human resources in tertiary institutions are required to implement these recommendations to reach the next level. Level assessment needs to be carried out for analysis of how much level has been achieved after the implementation of recommendations is carried out. the results of the recommendations APO12.05 can be seen in Table 13:

Table 13. APO12.05 Recommendation Results

\begin{tabular}{|l|l|}
\hline Domain & \multicolumn{1}{|c|}{ Recommendation } \\
\hline \multirow{7}{*}{ APO12.05 } & $\begin{array}{l}\text { a. Human Resources in tertiary institutions } \\
\text { should have a manifesto of the regulations } \\
\text { against the potential IT risks caused by } \\
\text { Human Errors. } \\
\text { buman Resources in tertiary institutions } \\
\text { should have clear operational standards basis } \\
\text { to prevent potential IT } \\
\text { c. Human Resources in tertiary institutions } \\
\text { should have a risk tolerance value to divide } \\
\text { IT risk by light criteria so that they are } \\
\text { acceptable and severe criteria that require } \\
\text { more aggressive action. }\end{array}$ \\
\hline
\end{tabular}

The recommendations in the APO12.05 domain have 3 published IT risk management recommendations. Human resources in tertiary institutions are required to implement these recommendations to reach the next level. Level assessment needs to be carried out for analysis of how much level has been achieved after the implementation of recommendations is carried out, And also can minimize the impact of IT risks. the results of the recommendations APO12.06 can be seen in Table 14:

Table 14. APO12.06 Recommendation Results

\begin{tabular}{|c|l|}
\hline Domain & \multicolumn{1}{c|}{ Recommendation } \\
\hline \multirow{3}{*}{ APO12.06 } & $\begin{array}{l}\text { a. Human Resources in universities should have } \\
\text { competent staff to make decisions when there } \\
\text { is a centralized IT risk. } \\
\text { buman Resources in higher education should } \\
\text { have quick action to respond to IT risks } \\
\text { conan Resources in tertiary institutions should } \\
\text { to respond to IT risks that have already } \\
\text { occurred. }\end{array}$ \\
\hline
\end{tabular}


The recommendations in the APO12.06 domain have 3 published IT risk management recommendations. Human resources in tertiary institutions are required to implement these recommendations to reach the next level. Level assessment needs to be carried out for analysis of how much level has been achieved after the implementation of recommendations is carried out. The above recommendations can be implemented by Human Resources in higher education to achieve the desired level.

\section{CONCLUSION}

Based on the results of research on the APO12 domain, which has a Capability Level value of 2.60, which means that at this level the implementation of business processes in Human Resources in higher education has carried out planning, supervision, and adjustment and the work results have been determined, observed and maintained properly. The Gap value in APO12 is known to be following concrete calculations by getting a Gap value of 1 level which means that a recommendation is needed to reach the desired level. Human Resources in tertiary institutions must have a regular schedule, either monthly or annually, make SOPs on IT risk management based on evaluation results, document risk history, plan before starting business processes, and update IT scenarios.

\section{REFERENCES}

[1] Soejanto, Joshua, and Andi Reza Perdanakusuma. 2018. "Evaluation of Information Technology Governance at PT. Aerofood Indonesia Soekarno Hatta Airport Cengkareng By Using."Journal of Information Technology Development and Computer Science (JPTIIK) Universitas Brawijaya 2 (11): 4714-21.

[2] Arief, M Habibullah. 2018. "Evaluation of Information Technology Risk Management Using the COBIT 5 Framework (Case Study at Perum Jasa Tirta I Malang)." Journal of Information Technology Development and Computer Science 2.

[3] Setyaningrum, Novia Dwi, Suprapto, and Ari Kusyanti. 2018. "Evaluation of Information Technology Risk Management Using the COBIT 5 Framework (Case Study: PT. Kimia Farma (Persero) Tbk - Watudakon Plant)." Journal of Information Technology and Computer Science Development 2 (1): 143-52.

[4] Megawati, and Syntia Ana. 2018. "Evaluation of Information Technology Risk Management Using the COBIT 5 Framework." Scientific Journal of Information Systems Engineering and Management 4 (2): 118-22.
[5] Firdaus, Nurfitri Zukhrufatul. 2018. "Evaluation of Information Technology Risk Management Using COBIT 5 IT Risk (Case Study: PT. Petrokimia Gresik)." Journal of Information Technology Development and Computer Science 2 (1): 91-100.

[6] Nanda Putra Wandita. 2014. "Evaluation of Information Technology Governance in Distance Education Systems Using the COBIT 5 Framework (Case Study: College of Police Science-Police Science College." Syarif Hidayatullah State Islamic University, Jakarta.

[7] ISACA. 2012a. Trust And Partnership A Business Framework for the Governance and Management of Enterprise IT.

[8] ISACA. 2012b. “COBIT 5.0. 2012. Main Framework Version 2.0.

[9] ISACA. 2012c. Isaca COBIT 5 Implementation.

[10] Arikunto, S. 2010. Research Procedures A Practical Approach. Rineka Cipta.

[11] ITGI.IT Governance institute. 2007.COBIT 4.1.IT Governance Institute.

[12] Jogiyanto, A. 2011. Information Technology Governance System. Publisher Andi.

[13] Prof. Dr. Sugiyono. 2019. Qualitative and Quantitative Research Methods and R \& D. M. Dr. Ir. Sutopo.S.Pd (ed.); 1st ed. ALFABETA, cv, Jalan Gegerkalong Hilir No. 84 .

[14] Putri,C.U. 2017. Risk Assessment of Information Technology Processes Based on the COBIT 5 Framework in the Helpdesk of the Sub-Directorate of Technology Services and Information Systems, Directorate of Information Technology and Information Systems Development (DPTSI) Sepuluh Institute of Technology. 241.

[15] S.Gondodiyoto. 2007. The Information Systems Audit and COBIT Approach.

[16] Stewart,JamesM,:Chapple,Mike;Gibson,D. 2015.CISSP (ISC)2 Certified Information Systems Security Professional Official Study Guide, $7^{\text {th }}$ Edition.Wiley

[17] Surendro, K. 2009.Implementation of Information Technology Governance, Information Technology

[18] Yunanda. 2009. Evaluation. http://repository.usu.ac.id /bits ream/ 123456789 /19622/4/Chapter II.pdf 